E. C. KORNFELD, E. J. FORNEFELD, G. B. KLINE, M. J. MANN, D. E. MORRISON,

R. G. JONES, R. B. WOODWARD* (HARVARD UNIVERSITY, CAMBRIDGE, USA)

The Total Synthesis of Lysergic Acid

J. Am. Chem. Soc. 1956, 78, 3087-3114, DOI: 10.1021/ja01594a039.

\section{The First Total Synthesis of Lysergic Acid}
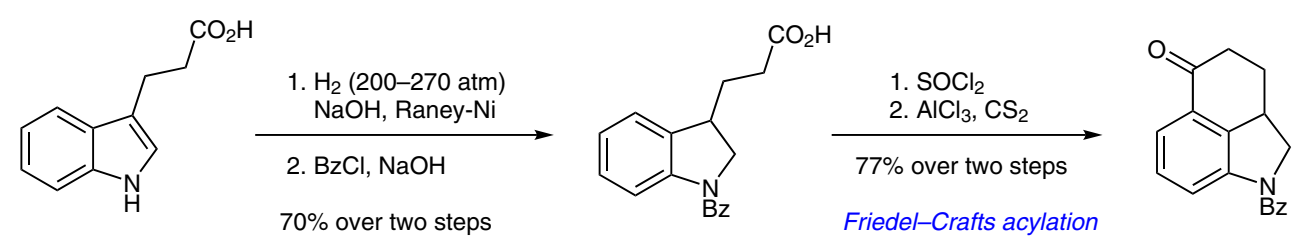

Schotten-Baumann reaction

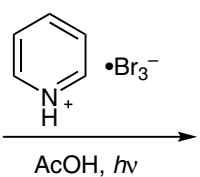

$69 \%$ yield<smiles>O=C1c2cccc3c2C(F)(CN3)CC1Br</smiles><smiles></smiles><smiles>CN1CC(=O)C=C2CC3(CNc4cccc2c43)C1</smiles>

aldol condensation
Category

Chemistry in

Medicine and Biology

\section{Key words}

ergot alkaloids

dihydroindoles

Schotten-Baumann reaction

Friedel-Crafts acylation
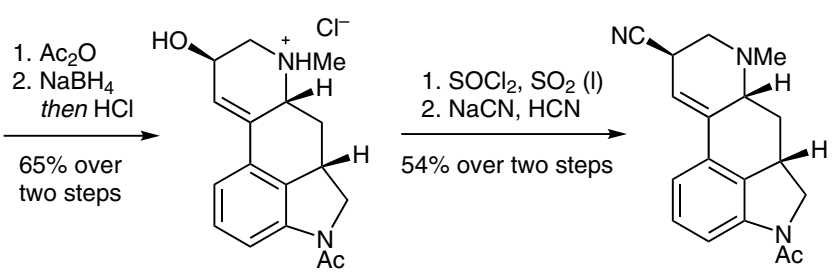

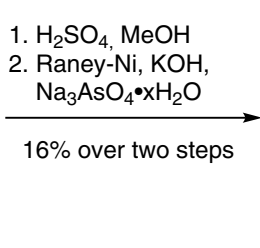

( \pm -Lysergic acid

Significance: Lysergic acid is the core motif of the ergoline alkaloid family and serves as a versatile precursor toward many of its biologically active amide derivatives. These lysergamides are potent agonists or antagonists of various dopamine and serotonin receptors and find applications for the treatment of many neurological disorders. Woodward and co-workers disclosed the first total synthesis of racemic lysergic acid in 1956.
Comment: Due to the high reactivity of indoles, Woodward and co-workers first reduced the heterocycle and worked with protected dihydroindole intermediates. Key ring-forming reactions include a Friedel-Crafts acylation and an aldol condensation. The indole portion was regenerated using heat-deactivated Raney nickel in the presence of sodium arsenate. 